\title{
$\underline{\text { Social Movements and Social Policy: New Research Horizons }}$
}

Across the globe, movements are confronting states and elites, challenging inequalities and mobilising for greater justice, a stronger voice, and progressive policy changes. In this article, I bridge the divide between Social Policy and the interdisciplinary field of Social Movement Studies. I examine how and why social movements, as actors in policy fields and social movement theories, matter for social policy. I argue that research on social movements as actors and engagement with social movement theories can open new horizons in Social Policy research by advancing our understanding of the politics of policy from a global perspective and strengthening our analytical and explanatory frameworks of agency, ideas, and power in the study of continuity and change of policy. 
Over the past decade, movements such as Black Lives Matter, Extinction Rebellion, Occupy, and the Indignados have confronted states and elites, challenging inequalities and mobilising for greater justice, democracy, and progressive policy changes. Some argue that we are living in a "social movement world"(Snow et al., 2019) in that protests have become a ubiquitous part of political bargaining as political and policy decisions are contested in the streets and squares across the globe, and that even amidst COVID restrictions, protests remained an integral part of the global political landscape (Press and Carothers, 2020). Periods of crisis are frequently characterised as critical junctures or "moments of rupture" that create windows of opportunity for transformations in social, political, and economic life (Della Porta, 2020: 556), as different ways of doing things become conceivable to both policymakers and the public. While periods of crisis present opportunities for transformation, the direction of change is uncertain and policy outcomes are contingent on the alignment of actors and the strategic choices they make.

In this article, engaging in a theoretical discussion that is informed by empirical research on social movements [SMs] (anonymised), I bridge the divide between Social Policy and the interdisciplinary field of Social Movement Studies. I adopt Dean's (2019) approach to differentiate between Social Policy as an academic field of study that "entails the study of social relations necessary for human wellbeing" and social policy, as a single or set of policies that "bear upon human wellbeing" (Dean, 2019 : 1-2). I examine how and why SMs as actors and SM theories matter for S/social P/policy. I argue that research on $\mathrm{SMs}$ as actors in policy spaces and engagement with SM theories can open new horizons in Social Policy research by advancing our understandings of the politics of policy from a global perspective and strengthening our analytical and explanatory frameworks of agency, ideas, and power in the study of continuity and change of policy. Moreover, I maintain that to have 
a fuller understanding of the potential of movements in relation to social policy, we need to examine not just their direct impacts on policies, but what transformations movements engender in culture, consciousness, and practices in everyday life, because such changes in norms, attitudes, and beliefs can lay the foundations for future policy transformations.

There are many definitions of SMs. Here I use Diani’s definition of SMs as "a plurality of individuals, groups and or organizations, engaged in political and/or cultural conflicts, on the basis of shared collective identities" who through "either joint communication and/or action" come to see themselves "as part of the side in a social conflict" (Diani, 1992: 2-3). SMs operate in the arena of civil society. However, unlike professionalised civil society organisations (e.g., nongovernmental organisation [NGOs]), whose service delivery and advocacy roles in the mixed economy of welfare have been extensively studied (Johansson et al., 2015), SMs are generally formed "to voice grievances and concerns about the rights, welfare, and well-being of themselves" (Snow et al., 2019: 1) and "to demand fundamental social change, the recognition of new identities, entry into the polity, the destruction of their enemies, or the overthrow of a social order - but seldom just 'reform"' (Tarrow, 2011) [emphasis added].

I begin with a literature review to consider how Social Policy scholars have studied the relationship of SMs to social policy. Building on this review, I identify two areas for future research: a) the study of SMs and their relationship to continuity and change in social policy and b) the study of the potential and limits of SMs' agency in imagining and enacting alternative and transformative social relations and practices of wellbeing and care.

\section{Social Policy and Social Movements: Bridging the fields}

In the 1970s, class-based labour movements were seen as having played an important role in the emergence of welfare states (Korpi, 1978, Esping-Andersen, 1990). While these studies and theoretical approaches (e.g., Power Resource Theory) recognised the power and 
agency of actors beyond the State (Korpi 1978) and the impact of active class mobilization, they did not "deny the importance of structured or hegemonic power" (Esping-Andersen, 1990: 99). Such approaches were important correctives to structuralist analyses of welfare state development; however, they were not without shortcomings. Critics argued there was an over-emphasis on class as opposed to other identities such as gender (Lewis, 1992), race and ethnicity (Williams, 1995) and that these approaches did not provide theoretical space to account for how citizenship rights are "recast and reconfigured" in societies (Hobson and Lindholm, 1997: 476-477).

In the 1990s, Social Policy scholarship began to engage with new social movement (NSM) theories asking how New Social Welfare Movements (Croft and Beresford, 1992) were mobilising around questions of social policy. NSMs are seen as distinct from the 'old' class-based movements in that they not only struggle "for the reappropriation of the material structure of production, but also for collective control over socio-economic development, i.e., for the reappropriation of time, of space, and of relationships in the individual's daily existence" (Melucci, 1980: 219). Research on SMs and their relationship to social policy emerged in an era of welfare state retrenchment, restructuring and transition in the industrialised West (Hobson and Lindholm, 1997) as scholars analysed movements' struggles for the legitimisation and recognition of new welfare identities (Barnes, 1999, Williams, 1999), how movements' cultural and symbolic challenges intersected with policy (Martin, 2001: 362), and the ways in which NSMs staked claims for welfare and "put on the agenda needs to do with personhood and wellbeing" that expanded the "meanings of redistribution, equality, universalism, and justice” (Williams, 1999: 668).

The focus on movements in Social Policy was part of a wider revival of interest in human agency, which had until that point been neglected in the discipline (Deacon and Mann, 1999: 413). Some of these studies of agency in social policy drew attention to the 
capacities of people to be creative and to be reflexive agents and how such actions were shaped by institutions and power relations (Lister, 2004, Williams, 1999).

There was much debate at the time as to whether NSMs were advancing material or post-material claims (Martin, 2001) and their ability to influence social policy (Myles and Quadango, 2002, Newman et al., 2008: 553). As Philipps contends, “'left' critics of identity politics" bemoaned the perceived retreat from class (Phillips, 2003: 263), arguing that NSMs were leading to the weakening of social solidarity. Feminist scholars challenged this as a false dichotomy, arguing that NSMs' demands for justice were about both the redistribution of material resources and the recognition of new identities (Fraser, 1995, Lister, 1997, Williams, 1999). Moreover, if we look beyond the Global North, the categories of 'old' versus 'new' movements are problematic, as old movements in formerly colonised countries were the anti-colonial movements, which did not have a clear class character (Fadee, 2017: 49) and historically movements in the Global South have advanced interconnected redistributive and recognition claims (Silva, 2015).

The emergence of the global 2010+ movements (e.g., the Arab Spring, the Indignados, and Occupy), led to a renewed interest in and research on the relationship between SMs and social policy (Díaz-Parra and Jover-Báez, 2016, Seckinelgin, 2016, Edmiston and Humpage, 2018). Scholars examined SMs challenging the privatization and commodification of welfare services (Mladenov, 2015, Roulstone and Morgan, 2009), austerity cuts (Harrison and Risager, 2016) and rising inequalities and precarity within and across countries (Runciman, 2016). As before, questions emerged about the potential of movements to impact policy (Kreiss and Tufekci, 2013).

SM scholars examine a range of questions around how and why movements emerge (Tilly and Tarrow, 2007), the relationship between contentious collective action and transformation (Jenkins, 1983, Tarrow, 2011, Della Porta, 2015) as well as the agency of 
movement actors (Melucci, 1980, Touraine, 1984, Pleyers, 2011, Jasper, 2010) and the significance of collective identity formation (Polletta and Jasper, 2001). One area which has long dominated debates in this field, is the question of impact. While some narrowly define the impact of movements as their ability to achieve policy change (Amenta et al., 2010), others view success in terms of movements gaining recognition as legitimate representatives for collective interests (Gamson, 1975), and their ability to change social values in order to "expand the range of ideas about what is possible", thus redefining the political agenda (Rochon and Mazmanian, 1993: 77), and bringing about transformations "in culture and consciousness, in collective self-definitions, and in the meanings that shape everyday life" (Polletta, 1997). Some even argue that evidence of success includes the increased "forms of (state) surveillance, militarization of police forces and other highly aggressive and intrusive forms of censorship and repression" (White and Wood, 2016: 570).

Given the ubiquity of movements today, it is worth once again asking the question posed by Rochon and Mazmanian nearly 30 years ago : "if the efficacy of mobilizing for policy change through SMs is so problematic, why are so many people doing it?" (1993: 76). Furthermore, if we look beyond the Global North, there is much evidence of how movements in Africa (Mottiar and Lodge, 2017), Asia (Shah and Lerche, 2021), Latin America (Anria and Niedzwiecki, 2016, Silva, 2015), and the Middle East (Bayat, 2013) are not only at the forefront of challenging inequalities, demanding social justice and advancing critiques of neoliberalism, but also in creating alternative models of care and wellbeing (Araujo, 2016, Saugier and Brent, 2017).

I agree with the wider approaches to understanding impact and now turn to examine how and why movements matter for S/social P/policy. I consider how a focus on SMs as actors and engagement with SM theories can contribute to and advance our understanding of 
the politics of policy and strengthen our analytical frameworks of continuity and change in social policy.

\section{Continuity and Change: Social Movements, Agency, Ideas, and Power Actors and Agency}

In researching continuity and change in social policy (Béland and Powell, 2016, Hall, 1993, Mahoney and Thelen, 2009) scholars have developed concepts and theories, including path dependency (Streeck and Thelen, 2005), punctuated equilibrium (Baumgartner and Jones, 1993), and ideational analysis to explain incremental as well as paradigmatic changes (Béland and Powell, 2016: 135). Until recently, this field of research was dominated by institutionalist scholars (Béland and Powell, 2016: 132) who tended to adopt a top-down, state-centric approach. They paid far less attention to how extra-institutional actors, including movements, create political opportunities through "discursive resources and patterns of mobilization" (Hobson and Lindholm, 1997: 480).

To overcome "excessive institutional determinism", Schneiberg and Lounsbury (2017) argue that there needs to be a more substantial shift from "an isomorphic institutional world of diffusion, path dependence and conformity toward conceptions of [policy] fields as sites of contestation, organized around multiple and competing logics and forms"

(Schneiberg and Lounsbury, 2017: 281). As Béland maintains, SM studies, with its focus on "the relationship between the formation of collective identities and political mobilization...is a field that has clear implications for policy research" (Béland, 2017: 10).

Within SM studies, structural theories of resource mobilization (Jenkins and Zald, 1997), political opportunities (Tarrow, 2011, Della Porta, 2020), and framing (Benford and Snow, 2000) have examined how movements seek to influence political and policy decisions. However, these structural approaches focus on how movements operationalise windows of opportunity created in moments of crisis and do not give sufficient attention to the agency of 
SMs in creating opportunities. Recent theorising in SM studies has sought to bring together the structural and cultural paradigms (Melucci, 1980, Polletta, 1997), to consider both the agency of actors and how they are constrained by structural power. Strategic interactionism theory (Duyvendak and Jasper, 2015), which is informed by modern complexity theory, is such a cultural-strategic model. It posits that "we cannot explain social outcomes by adding up the separate goals and actions of particular actors or groups taken individually" and that instead, we should focus on the interactions between actors and how the arenas in which they work shape their choices and actions (Goldstone, 2015: 236). These approaches challenge monolithic interpretations of the State, arguing that devolution, deregulation, and decentralization have created cleavages between local and national state actors which require a rethinking of institutionalist theories (Verhoeven and Duyvendak, 2017).

Applying strategic interactionism, Verhoeven and Duyvendak examine the phenomenon of governmental activism in which politicians, civil servants and governmental actors engage with movements in contentious claim-making "to alter or redress policies proposed by other governmental players" (2017: 565). Verhoeven and Duyvendak (2017) discuss instances of governmental activism. One example of governmental activism involved a group of European mayors joining almost 100 NGOs and SMs in Barcelona in 2016 to draft a declaration demanding the end of negotiations by EU governments on the Transatlantic Trade and Investment Partnership. A second instance of governmental activism examined how the Municipal Executive in Barendrecht, a Dutch municipality, joined the local CO2isNo action group by taking part in weekly secret meetings to coordinate protest efforts against national ministers around climate policies (Verhoeven and Duyvendak, 2017: 564)

While the importance for movements of building allies within state institutions has long been stressed (Lipsky, 1968, Schumaker, 1975, Fox Piven and Cloward, 1978), the onus has been on movement actors to build the alliances. Governmental activism, in contrast, 
considers how and why governmental actors seek out and build alliances with SMs to achieve their aims. Institutionalist research on continuity and change in social policy can benefit from engaging with SM theories and shifting the lens from a state-centric, top-down focus to examine SMs' agency in policy spaces and, as I discuss below, how SMs "spur change through ideas that contest the status quo" (Schmidt, 2011: 118).

\section{Ideas and Power}

A growing body of literature in Social Policy and other social sciences emphasises the role of ideas and discourses in policy continuity and change (Schmidt, 2011, Béland and Powell, 2016, Piketty, 2020). Schmidt's model of discursive institutionalism examines how “substantive ideas developed and conveyed by 'sentient' agents" inform "policy-oriented actions, which in turn serve to alter (or maintain) 'institutions"” (Schmidt, 2011: 177). Meanwhile, in his new book, Capital and Ideology, Piketty examines how ideas have sustained inequality for the past millennium. He contends that "inequality is neither economic nor technological; it is ideological and political" and that manifestations of inequality are shaped by “each society’s conception of social justice and economic fairness and by the relative political and ideological power of contending groups and discourses" (Piketty, 2020: 7). While critics welcome Piketty's focus on ideologies, they argue that ideological change cannot simply be viewed as a matter of choice (Shah and Lerche, 2021: 95), adding that struggles over ideas do not materialize in a vacuum, but that they emerge in the context of particular states with their "unique histories, bureaucratic capacities, and levels of autonomy" (Sanchez-Anchochea, 2021: 128).

Drawing on theories of action and collective identity formation, SM scholars examine how activists' agency, ideas, and cultural understandings translate into repertoires of action aimed at bringing about changes in policies, politics, cultures, and societies (Touraine, 1984, Jasper, 2010, Pleyers, 2011). They view movements as sources of challenge and creativity in society and as fertile spaces where actors question dominant structures, 
discourses, and ideas and dare to imagine the unimaginable (Escobar, 2004). Alongside mobilising for or against specific policies and challenging hegemonic ideologies and systems of governmentality (e.g., anti-capitalist or anti-racist movements), movements also enact alternative social relations and practices. In the next section, I turn to examine the significance of such prefigurative practices.

\section{From imagining to enacting alternatives: social movements, prefigurative politics and alternative practices of wellbeing}

Prefiguration as a concept emerged out of anarchism and is a form of politics that was adopted by the alter-globalisation movement of the 1990s (Pleyers, 2011) and recent antiausterity and pro-democracy movements (Glasius and Pleyers, 2013). Prefigurative politics is distinct from the "grandiose politics of "the Revolution"” of the Left (Escobar, 2004: 221) and prefiguration is something people do rather than "a theory of social change that first analyses the current political landscape, develops an alternative model in the form of a predetermined goal, then sets out a five-year plan for changing the existing landscape into that predetermined goal" (Maeckelbergh, 2011: 3). Movements adopting prefigurative practices work in local contexts, creating micro-utopias (Díaz-Parra and Jover-Báez, 2016) and everyday forms of resistance (Bayat, 2013) that exist in parallel with, or in the course of, adversarial action (Cornish, 2021).

Decolonising efforts in the social sciences, including in Social Policy, have generated epistemological questions that challenge the "limits of Western-centric ways of knowing" and seek to draw "hope and inspiration from anti-racist and anti-imperial social justice movements"(Bhambra et al., 2020: 138). Post-development scholars critique the hegemonic forms of neoliberal governmentality and universalist conceptualisations of wellbeing (Escobar, 2004), instead arguing for "pluriversal paths" to address the multiple, interconnected systemic crises of the present (Kothari et al., 2019: xxi). They examine how 
"movements for wellbeing" in the Global South adopt transformative initiatives and practices of care, for humans as well as non-human species and nature (e.g., buen vivir, ubuntu, swaraj), which differ from "mainstream or reformist" policy approaches in their focus on root causes (Kothari et al., 2019: xxix) and their embrace of "more liberatory socio-economic relationships" (Araujo, 2016: 743). The ideas and models discussed by post-development scholars may seem quite utopian or radical, but there is a long tradition of "Utopian" thinking in Social Policy dating back to the $19^{\text {th }}$ century (Williams, 2016: 642), which involved imagining and enacting alternative futures.

In Latin America, SMs have been active in creating alternative models and practices of wellbeing that reject the exploitative and extractive practices of capitalist social relations (Araujo, 2016, Saugier and Brent, 2017). The Social and Solidarity Economy agenda (SSE) in South America, which was built from the "bottom-up" through collective processes led by "social and indigenous movements" was created to meet "the needs of individuals and communities rather than trying to maximize profits or financial gains" (Saugier and Brent, 2017: 262). In the 2000s, SSE was taken up by many left-of-centre governments in the region. Similarly, the concept of buen vivir (good living), which is rooted in Andean indigenous traditions, became the basis for the development of social policies in Ecuador and Bolivia. While both SSE and buen vivir were embraced by policy makers and in the case of buen vivir, even achieved "the status of a dominant ideology", in practice there were unintended and "contradictory" policy outcomes (Caria and Dominguez, 2016: 27) as some of the more transformative aspects were watered down in the course of implementation to limit opposition from economic and political elites (Saugier and Brent, 2017).

In the context of austerity and cuts to public welfare in Europe, alternative forms of social relations have emerged to meet wellbeing and care needs that are structured around mutual aid and solidarity (Boersma et al., 2019, Griffiths, 2019) (anonymised). From 2013- 
2014 and 2017-2019, colleagues and I interviewed solidarity activists in Greece who spoke about the failure of the State to deliver services and support to those affected by austerity and how this had led to the rise of solidarity initiatives. Solidarity initiatives included electricity reconnections to homes; food distribution networks; and solidarity centres in different neighbourhoods which provided meals, second-hand clothing, classes, lending libraries, etc. These initiatives were founded on a highly politicized understanding of solidarity which involved mutual aid, but also encompassed an array of progressive, anti-systemic actions. Beginning in 2015, these solidarity initiatives expanded to support migrants in Greece, including founding solidarity accommodation sites for migrants, such as the Pikpa camp in Lesvos and City Plaza Hotel in Athens. These solidarity camps stood in stark contrast with the highly securitized State-run refugee camps, in that they were created on the principles of solidarity and empowerment, and included the active participation of migrants in the daily operations and decision making (anonymised). Similar solidarity initiatives to support migrants exist in France, Germany, Italy, and the Netherlands (Bhimji, 2016, Boersma et al., 2019, Sandri, 2018, Sinatti, 2019). These solidarity initiatives are significant not only in that they are meeting welfare needs in the absence of state support, but that they are concurrently mobilising for structural changes to the governance of asylum and migration. While these solidarity initiatives succeed in delivering support to migrants, their ability to achieve wider structural changes in national and EU migration and asylum policies has been limited.

On the one hand, the above examples demonstrate the agency of movements to imagine and enact alternative social relations and practices of wellbeing and care. On the other hand, they highlight the challenges movements face in achieving more structural and systemic changes. These cases underscore the need to take a longer-term view and to consider how movements interact with the different stages of the policy process, from agenda setting to decision-making and implementation. The lack of systemic change should not be 
read as a failure, but rather seen as an ongoing attempt towards wider, transformative changes that require tackling systems and structures of power, which, unsurprisingly, will take time to achieve. Furthermore, even in instances when movements do not achieve their desired policy impact, processes of sedimentation (Della Porta 2020) and the seeding of ideas in one period can lead to the birth of "a new generation of ideas, actors, and practices, awaiting to flourish when the next spring returns" (Saugier and Brent, 2017: 274).

\section{Conclusion}

I began the article asking by how and why SMs as actors and SM theories matter for S/social P/policy. I argued that a focus on SMs as actors and an engagement with SM theories and concepts can advance our understanding of the politics of policy and strengthen our analytical and explanatory frameworks of the role of agency, ideas, and power in the processes of policy continuity and change. Whilst acknowledging the agency and potential of movements, I do not suggest we ignore the constraints of institutions and structural power; after all, structural power is also "the power not to listen" (Schmidt, 2011: 121). The question we should be asking is not whether SMs matter in or for S/social $\mathrm{P} /$ policy, but under which circumstances and due to what factors can movements' ideas and actions influence and inform S/social P/policy.

Gramsci viewed civil society as the terrain in which hegemonic ideas and structures could be contested (Gramsci, 1971). Today, neoliberalism is a hegemonic governing rationality which devalues common ends and public goods, opposes progressive taxation and advocates a radical reduction in welfare state provisions and protections, as well as the scrapping of wealth redistribution as a social and economic policy approach (Brown, 2015: 28 - 30). In this "age of austerity", retaining the "neoliberal hegemony" depends on focusing on the "irrationality" of redistribution (Farnsworth and Irving, 2012: 133-134). Scholars argue that if transformative changes to current welfare systems and social policies are to 
occur, those changes will most likely emerge from the sphere of civil society (Crouch, 2011) in which movements represent "the greatest move away from neoliberal ideas" (Thatcher and Schmidt, 2013: 426). For these reasons it makes sense to examine the role of SMs as actors in national and global social policy fields who imagine and enact ideas and practices that challenge both specific policies and wider systems and structures of power. SM theories have clear implications for S/social P/policy and can strengthen our analytical frameworks of the politics of policy and processes of continuity and change.

Finally, in acknowledging the transformative potential of progressive SMs, we should not ignore the recent resurgence or intensification of authoritarian and even fascist political movements (Bhambra et al., 2020: 137). It is important to adopt critical approaches to avoid normative traps. To date, however, both SM studies and Social Policy have largely focused on progressive movements that promote social justice, rather than on movements that advance welfare chauvinism and social exclusion (Krause and Giebler, 2020). It will be important to consider the movement-countermovement dynamics and the potential of populist far right movements to influence and shape social policy. Moreover, and related to the above, it is important to remember that progressive politics do not magically emerge from aggrieved identities (Chun et al., 2013 : 937) and that movements themselves are sites of struggle between attempts at inclusiveness and enduring tendencies to reproduce existing hierarchies (anonymised). Looking to the future, there are many fruitful areas for Social Policy research to engage with social movement theories and social movement actors; in this article, I have only touched upon the tip of the iceberg.

Amenta, E., Caren, N., Chiarello, E. \& Su, Y. (2010), 'The Political Consequences of Social Movements', Annual Review of Sociology, 36, 287-30.

Anria, S. \& Niedzwiecki, S. (2016), 'Social Movements and Social Policy: the Bolivian Renta Dignidad', Studies of Comparative and International Development, 51, 308-327. 
Araujo, E. (2016) 'Consensus and activism through collective exchanges: a focus on El Camabaleche, Mexico', International Journal of Sociology and Social Policy, 36, 11/12, 741-755. .

Barnes, M. (1999) 'Users as citizens: collective action and the local governance of welfare', Social Policy \& Administration, 33, 1, 73-90.

Baumgartner, F. \& Jones, B. (1993) Agendas and Instability in American Politics, Chicago: University of Chicago.

Bayat, A. (2013), Life as Politics: How Ordinary People Change the Middle East, Palo Alto: Stanford University Press.

Béland, D. (2017), 'Identity politics and public policy', Critical Policy Studies, 11, 1, 1- 18.

Béland, D. \& Powell, M. (2016), 'Continuity and Change in Social Policy', Social Policy and Administration, 50, 2, 129-147.

Benford, R. D. \& Snow, D. A. (2000), 'Framing Processes and Social Movements: An Overview and Assessment', Annual Review of Sociology 26, 611-639.

Bhambra, G., Medien, K. \& Tilley, L. (2020), 'Theory for a global age: From nativism to neoliberalism and beyond', Current Sociology, 68, 2, 137-148.

Bhimji, F. (2016), 'Visibilities and the Politics of Space: Refugee Activism in Berlin', Journal of Immigrant and Refugee Studies, 14, 4, 432-450.

Boersma, K., Kraiukhina, A., Larruina, R., Lehota, Z. \& Nury, E. O. (2019), 'A port in a storm: Spontaneous volunteering and grassroots movements in Amsterdam', Social Policy \& Administration, 53, 5, 728-742.

Brown, W. (2015), Undoing the Demos: Neoliberalism's Stealth Revolution, New York: Zone Books.

Caria, S. \& Dominguez, R. (2016), 'Ecuador's Buen vivir: A New Ideology for Development', Latin American Perspectives, 43, 1, 18-33.

Chun, J. J., Lipsitz, G. \& Shin, Y. (2013), 'Intersectionality as a Social Movement Strategy: Asian Immigrant Women Advocates', Signs: Journal of Women in Culture and Society, 38, 4, 917-940.

Cornish, F. (2021), 'Grenfell Changes Everything? Activism beyond hope and despair', Critical Public Health, online first.

Croft, S. \& Beresford, P. (1992), 'The Politics of Participation', Critical Social Policy, 12, $35,20-44$.

Crouch, C. (2011), The Strange Non-Death of Neoliberalism, Cambridge: Polity Press.

Deacon, A. \& Mann, K. (1999), 'Agency, Modernity and Social Policy', Journal of Social Policy, 28, 3, 413-435.

Dean, H. (2019) Social Policy, Cambridge: Polity.

Della Porta, D. (2015), Social Movements in Times of Austerity, Cambridge: Polity.

Della Porta, D. (2020), 'Protests as critical junctures: some reflections towards a momentous approach to social movements', Social Movement Studies, 19, 5/6, 556-575.

Diani, M. (1992), 'The Concept of Social Movement', Sociological Review, 40, 1, 1-25.

Díaz-Parra, I. \& Jover-Báez, J. (2016), 'Social movements in crisis? From the 15-M movement to the electoral shift in Spain', International Journal of Sociology and Social Policy, 36, 9/10, 680-694.

Duyvendak, J. W. \& Jasper, J. M. (2015), Players and arenas: the interactive dynamics of protest, Amsterdam: Amsterdam University Press.

Edmiston, D. \& Humpage, L. (2018), 'Resistance or resignation to welfare reform? The activist politics for and against social citizenship', Policy \& Politics, 46, 3, 467-484.

Escobar, A. (2004), 'Beyond the Third World: imperial globality, global coloniality and antiglobalisation movements', Third World Quarterly, 25, 1, 207-230. 
Esping-Andersen, G. (1990), 'Three Political Economies of the Welfare State', International Journal Of Sociology, 20, 3, 92-123.

Fadee, S. (2017), 'Bringing in the South: towards a global paradigm for social movement studies', Interface, 9, 2, 45-60.

Farnsworth, K. \& Irving, Z. (2012), 'Varieties of crisis, varieties of austerity: social policy in challenging times', Journal of Poverty and Social Justice, 20, 2, 133-147.

Fox Piven, F. \& Cloward, R. (1978), Poor People's Movements: why they succeed, how they fail, New York: Penguin.

Fraser, N. (1995), 'From redistribution to recognition? Dilemmas of justice in a 'postsocialist' age', New Left Review, 212, July/August, 68-92.

Gamson, W. (1975), The Strategy of Social Protest, Belmont: Wadsworth Publishing.

Glasius, M. \& Pleyers, G. (2013), 'The Global Moment of 2011: Democracy, Social Justice and Dignity', Development and Change 44, 3, 547-567.

Goldstone, J. A. (2015), 'Simplicity vs. Complexity in the Analysis of Social Movements' in Duyvendak, J. W. \& Jasper, J. M. (eds.) Breaking down the State: Protestors Engaged, Amsterdam: Amsterdam University Press.

Gramsci, A. (1971), Selections from the Prison Notebooks, London: Laurence and Wishart. .

Griffiths, M. (2019), 'These Days Are Ours: Young Disabled People's Experiences of Activism and Participation in Social Movements', in Berghs M., Chataika, T., ElLahib, Y. \& Dube, K. (eds.) The Routledge Handbook of Disability Activism. London: Routledge.

Hall, P. A. (1993), 'Policy Paradigms, Social Learning, and the State', Comparative Politics, 25, 3, 275-296.

Harrison, Y. N. A. \& Risager, B. S. (2016), 'Convergence as Organization: Blockupy against the ECB', International Journal of Sociology and Social Policy, 36, 11/12, 843-859.

Hobson, B. \& Lindholm, M. (1997), 'Collective Identities, Women's Power Resources and the Making of Welfare States', Theory and Society, 26, 4, 475-508.

Jasper, J. M. (2010), 'Social Movement Theory Today: Toward a Theory of Action?', Social Compass, 4, 11, 965-976.

Jenkins, J. C. (1983), 'Resource mobilization theory and the study of social movements', Annual Review of Sociology 9.

Jenkins, J. D. \& Zald, M. N. (1997), 'Resource Mobilization and Social Movements', American Journal of Sociology, 82, 6, 1212 -1241.

Johansson, H., Arvidson, M. \& Johansson, S. (2015), 'Welfare Mix as a Contested Terrain: Political Positions on Government-Non-profit Relations at National and Local Levels in a Social Democratic Welfare State', VOLUNTAS, 26, 1601-1619.

Korpi, W. (1978), The Working Class in Welfare Capitalism: Work, Unions and Politics in Sweden, London: Routledge.

Kothari, A., Salleh, A., Escobar, A., Demaria, F. \& Acosta, A. (2019),Pluriverse: A PostDevelopment Dictionary, New Delhi: Tulika Books.

Krause, W. \& Giebler, H. (2020), 'Shifting Welfare Policy Positions: The Impact of Radical Right Populist Party Success Beyond Migration Politics', Representation, 56, 3, 331348.

Kreiss, D. \& Tufekci, Z. (2013), 'Occupying the Political: Occupy Wall Street, Collective Action, and the Rediscovery of Pragmatic Politics', Cultural Studies - Critical methodologies, 13, 3, 163-167.

Lewis, J. (1992), 'Gender and the Development of Welfare Regimes', Journal of European Social Policy 2, 3, 159-173.

Lipsky, M. (1968), 'Protest as a political resource', American Political Science Review, 62, 4, 1144-1158. 
Lister, R. (1997), 'Citizenship: Towards a Feminist Synthesis', Feminist Review, 57, 28-48.

Lister, R. (2004), Poverty, Cambridge: Polity.

Maeckelbergh, M. (2011), 'Doing is Believing: Prefiguration as Strategic Practice in the Alterglobalization Movement', Social Movement Studies, 10, 1, 1-10.

Mahoney, J. \& Thelen, K. (2009), Explaining Institutional Change: Ambiguity, Agency, and Power, New York: Cambridge University Press.

Martin, G. (2001), 'Social movements, welfare and social policy: a critical analysis', Critical Social Policy, 21, 3, 361-383.

Melucci, A. (1980), 'The new social movements: A theoretical approach', Social Science Information, 19, 2, 199-226.

Mladenov, T. (2015), 'Neoliberalism, postsocialism, and disability', Disability \& Society, 30, 3, 445-459.

Mottiar, S. \& Lodge, T. (2017), 'The Treatment Action Campaign and the South African State, 2009-2016', Social Dynamics: A journal of African studies, 43, 1, 103-117.

Myles, J. \& Quadango, J. (2002), 'Political Theories of the Welfare State', Social Service Review, 76, 1, 34-57.

Newman, J., Glendinning, C. \& Hughes, M. (2008), 'Beyond modernisation? Social care and the transformation of welfare governance', Journal of Social Policy, 37, 4, 531-557.

Phillips, A. (2003), 'Recognition and the struggle for political violence', in Hobson, B. (ed.) Recognition Struggles and Social Movement. Cambridge: Cambridge University.

Piketty, T. (2020), Capital and Ideology, Cambridge: Harvard University.

Pleyers, G. (2011), Alter-Globalization: Becoming Actors in the Global Age, Cambridge: Polity.

Polletta, F. (1997), 'Culture and Its Discontents: Recent Theorizing on the Cultural Dimension of Protest', Sociological Inquiry 67, 4, 431-450.

Polletta, F. \& Jasper, J. M. (2001), 'Collective Identity and Social Movements', Annual Review of Sociology, 27, 283-305.

Press, B. \& Carothers, T. (2020), Worldwide Protests in 2020: A Year in Review. [Online]. Carnegie Endowment, https://carnegieendowment.org/2020/12/21/worldwideprotests-in-2020-year-in-review-pub-83445 [Accessed 17/03/2021].

Rochon, T. R. \& Mazmanian, D. (1993), 'Social Movements and the Policy Process', Annals of the American Academy of Political and Social Science, 528, 1, 75-87

Roulstone, A. \& Morgan, H. (2009), 'Neo-liberal individualism or self-directed support: are we all speaking the same language on modernising adult social care?', Social Policy and Society, 8, 3, 333-345.

Runciman, C. (2016), 'Mobilising and organising in precarious times', International Journal of Sociology and Social Policy, 36, 9/10, 613-628.

Sanchez-Anchochea, D. (2021), 'All about ideology? Reading Piketty's with Latin American lenses', British Journal of Sociology, 72, 1, 125-138.

Sandri, E. 2018. 'Volunteer Humanitarianism': volunteers and humanitarian aid in the Jungle refugee camp of Calais. Journal of Ethnic and Migration Studies, 44, 65-80.

Saugier, M. \& Brent, Z. 2017. 'Social and Solidarity Economy in South American regional Governance'. Global Social Policy, 17, 259-278.

Schmidt, V. A. 2011. 'Speaking of change: why discourse is key to the dynamics of policy transformation', Critical Policy Studies 5, 106-126.

Schneiberg, M. \& Lounsbury, M. 2017. Social Movements and the Dynamics of Institutions and Organisations. In: Greenwood, R., Oliver, C., Lawrence, T. B. \& Meyer, R. E. (eds.) The Sage Handbook of Organizational Institutionalism. London: Sage.

Schumaker, P. 1975. 'Policy Responsiveness to Protest-Group Demands'. The Journal of Politics, 37, 488-521. 
Seckinelgin, H. 2016. 'Social policy and conflict: the Gezi Park-Taksim demonstrations and uses of social policy for reimagining Turkey', Third World Quarterly, 37, 264-280.

Shah, A. \& Lerche, J. (2021), 'Black Lives Matter, Capital and Ideology', British Journal of Sociology, 72, 1, 93-105.

Silva, E. (2015), 'Social Movements, Protest and Policy', European Review of Latin American and Caribbean Studies, 100, 27-39.

Sinatti, G. (2019), 'Humanitarianism as Politics: Civil Support Initiatives for Migrants in Milan's Hub', Social Inclusion., 7, 2, 139-148.

Snow, D. A., Soule, S., Kriesi, H. \& Mccammon, H. J. (2019), 'Introduction: Mapping and Opening Up the Terrain', in Snow, D. A., Soule, S., Kriesi, H. \& Mccammon, H., J. (eds.) Wiley Blackwell Companion to Social Movements. second ed. New York: Wiley Blackwell.

Streeck, W. \& Thelen, K. (2005), Beyond Continuity: Institutional Change in Advanced Political Economies, Oxford: Oxford University.

Tarrow, S. (2011), Power in Movement Cambridge: Cambridge University.

Thatcher, M. \& Schmidt, V. A. (2013), 'Conclusion: Explaining the resilience of neoliberalism and possible pathways out', in Schmidt, V. A. \& Thatcher, M. (eds.) Resilient Liberalism in Europe's Political Economy. Cheltenham: Edward Elgar.

Tilly, C. \& Tarrow, S. (2007), Contentious Politics, Boulder: Paradigm Publishers.

Touraine, A. (1984), Le retour de l'acteur [The Return of the Actor], Paris: Fayard.

Verhoeven, I. \& Duyvendak, J. W. (2017), 'Understanding governmental activism', Social Movement Studies, 16, 5, 564-577.

White, R. J. \& Wood, P. B. (2016), 'Guest Editorial', International Journal of Sociology and Social Policy, 36, 9/10, 580-577.

Williams, F. (1995), 'Race/Ethnicity, Gender, and Class in Welfare States: A Framework for Comparative Analysis', Social Politics, 2, 2, 127-159.

Williams, F. (1999), 'Good-enough Principles for Welfare ' Journal of Social Policy, 28, 4 , 667-687.

Williams, F. (2016), 'Critical Thinking in Social Policy: The Challenges of Past, Present and Future', Social Policy \& Administration 50, 6, 628-647 